University of Nebraska - Lincoln

DigitalCommons@University of Nebraska - Lincoln

USDA National Wildlife Research Center - Staff Publications
U.S. Department of Agriculture: Animal and Plant Health Inspection Service

April 1998

\title{
Predation on Atlantic Salmon Smolts by Striped Bass after Dam Passage
}

Bradley F. Blackwell

University of Massachusetts, Amherst, bradley.f.blackwell@aphis.usda.gov

Francis Juanes

University of Massachusetts, Amherst, Massachusetts

Follow this and additional works at: https://digitalcommons.unl.edu/icwdm_usdanwrc

Part of the Environmental Sciences Commons

Blackwell, Bradley F. and Juanes, Francis, "Predation on Atlantic Salmon Smolts by Striped Bass after Dam Passage" (1998). USDA National Wildlife Research Center - Staff Publications. 619.

https://digitalcommons.unl.edu/icwdm_usdanwrc/619

This Article is brought to you for free and open access by the U.S. Department of Agriculture: Animal and Plant Health Inspection Service at DigitalCommons@University of Nebraska - Lincoln. It has been accepted for inclusion in USDA National Wildlife Research Center - Staff Publications by an authorized administrator of DigitalCommons@University of Nebraska - Lincoln. 


\title{
Predation on Atlantic Salmon Smolts by Striped Bass after Dam Passage
}

\author{
BRADLEY F. BLACKWELL 1 \\ Department of Forestry and Wildlife Management, Holdsworth Natural Resources Center \\ University of Massachusetts, Amherst, Massachusetts 01003, USA \\ Francis JuANES \\ Department of Forestry and Wildlife Management, Holdsworth Natural Resources Center and \\ Graduate Program in Organismic and Evolutionary Biology \\ University of Massachusetts, Amherst, Massachusetts 01003, USA
}

\begin{abstract}
We documented predation on smolts of Atlantic salmon Salmo salar by striped bass Morone saxatilis foraging in the tailrace of the Essex Dam on the Merrimack River, Lawrence, Massachusetts, and assessed factors that may affect smolt susceptibility to predation. During $6 \mathrm{~d}$ of diurnal angling from 6 to 28 May, we captured 212 striped bass, 41 of which contained prey remains. More than $48 \%$ of striped bass that contained prey had consumed smolts. Atlantic salmon smolts composed more than $80 \%$ of the total mass of prey remains recovered and included both individuals of stocked-fry and stocked-smolt origin. Based on information from this pilot study, a focused investigation of striped bass predation on smolts after passage of the Essex Dam began in 1998.
\end{abstract}

Because smolts of Atlantic salmon Salmo salar begin seaward migration from New England rivers during early spring (Moring 1987; Moring et al. 1995), there is potential overlap with the arrival of striped bass Morone saxatilis migrating from the Chesapeake Bay and Hudson River (see Boreman and Lewis 1987). Warner and Kynard (1986) suggested that subadult striped bass might concentrate below hydroelectric dams and consume injured or moribund anadromous fish. Further, in recent years striped bass numbers have increased as a result of restoration, protection of nursery areas, and limits on numbers and sizes of fish taken by sport and commercial anglers (Field 1997).

Our objectives were to (1) document whether smolts contribute to the diet of striped bass foraging in the tailrace of the Essex Dam on the Merrimack River in Lawrence, Massachusetts, (2) identify evidence of injury to smolts prior to predation, (3) determine the origin (i.e., if hatchery-

\footnotetext{
* Corresponding author: nwrcsandusky@1rbcg.com

${ }^{1}$ Present address: U.S. Department of Agriculture, Animal and Plant Health Inspection Service, National Wildlife Research Center, 6100 Columbus Avenue, Sandusky, Ohio 44870-9660, USA.
}

reared fish stocked as fry or as smolts) of smolts consumed by striped bass, and (4) assess the contribution of smolts to the striped bass diet, relative to other prey collected.

\section{Study Area}

The Merrimack River basin drains an area of $12,975 \mathrm{~km}^{2} ; 76 \%$ of the drainage is in central New Hampshire and the remainder is in northeastern Massachusetts (Stolte 1994). More than $60 \%$ of habitat suitable for smolt production in the basin is within the Pemigewasset River (Stolte 1994), which forms the headwaters of the Merrimack River. In rearing habitat within the Pemigewasset River as well as in other areas in the Merrimack River basin, unfed fry are stocked from April through June and remain in the river system for approximately 2 years. From the Pemigewasset River to the mouth of the Merrimack River (210 river km from the ocean), migrating smolts encounter seven hydropower facilities and one earthen dam constructed for flood control (see Blackwell et al. 1998). However, fish stocked as smolts, from late March through April, begin migration approximately 70 river $\mathrm{km}$ from the ocean and encounter two hydroelectric dams.

This pilot study was conducted at the Essex Dam, the lowermost dam on the Merrimack River (approximately 49 river $\mathrm{km}$ from the mouth). The Essex Dam maintains a gross head (i.e., the difference between reservoir elevation and point of discharge) of $9.14 \mathrm{~m}$, has two turbines with 224$\mathrm{m}^{3} / \mathrm{s}$ capacity, and is outfitted with a downstream bypass. However, the downstream bypass is considered ineffective in passing Atlantic salmon smolts, and the effects of turbine passage at the Essex Dam are unclear (J. Warner, U.S. Fish and Wildlife Service [USFWS], personal communication). 


\section{Methods}

Striped bass were captured by angling in the tailrace of the Essex Dam from a structure immediately below the powerhouse. We used artificial lures resembling smolts in color or shape. Angling for striped bass was initiated on 6 May 1997 and sampling occurred from 0845 to 1700 hours (when facility personnel were on station). Sampling was initiated when river flows had decreased such that the tailrace area could be accessed safely and angling equipment could be used efficiently. We ended our sampling in accordance with an arbitrary limit placed on our state collector's permit that reflected the pilot status of our investigation. Scale samples, fork length $(\mathrm{cm})$, mass $(\mathrm{kg})$, and date of capture were recorded for each striped bass. Prey remains were collected from striped bass by gastric lavage by using a bilge pump with 4,136 L/h capacity.

Prey remains were stored on ice and placed in freezers upon return to the laboratory. For prey identification we used keys by Robins et al. (1986) and Scott and Scott (1988) and a reference collection of fish scales, vertebrae, cleithra, and hatchery-reared smolts. Additional data recorded for the prey items recovered included mass $(\mathrm{g})$; a subjective digestion grade of 1 for fresh, 2 for slightly digested, 3 for advanced digestion, or 4 for bone; and a length grade of 1 for intact, 2 for reasonably accurate, and 3 for a vertebral column without head or tail (see Harrison et al. 1983). Scale analysis and fork length were used to distinguish the origin of recovered smolts. Also, evidence of injury to smolts from turbine blades or abrasion was noted.

Finally, we calculated three statistics to describe the contribution of each prey taxon to the striped bass diet. Frequency of occurrence-the percentage of all striped bass that contained prey and had consumed a particular prey item-provided a measure of rarity of each prey taxon in the diet. We defined the gravimetric contribution of each prey taxon to the diet, the mean percent mass, as the total gravimetric percentage of a taxon relative to the total mass of prey consumed for all striped bass, divided by the number of striped bass containing prey remains. The numerical contribution of each prey taxon to the diet was simply the total number of individuals of each taxon consumed during the sampling period. Each statistic has associated biases when considered alone (Reintjes and King 1953; Hyslop 1980), but prey taxa that are well represented relative to each measure can
TABLE 1.-Prey categories and statistics for prey remains recovered from striped bass $(N=41)$ collected in the tailrace of the Essex Dam on the Merrimack River.

\begin{tabular}{|c|c|c|c|}
\hline Prey category & $\begin{array}{l}\text { Fre- } \\
\text { quency } \\
\text { of } \\
\text { occur- } \\
\text { rence }\end{array}$ & $\begin{array}{c}\text { Mean } \\
\text { percent } \\
\text { mass } \\
(\mathrm{g})\end{array}$ & $N$ \\
\hline Atlantic salmon & 48.8 & 45.8 & 32 \\
\hline Atlantic salmon (suspected) ${ }^{\mathrm{a}}$ & 51.2 & 36.2 & 28 \\
\hline Unidentified fish (not Atlantic salmon) ${ }^{b}$ & 9.8 & 8.2 & 4 \\
\hline Unidentified fish ${ }^{\mathrm{c}}$ & 4.9 & 2.5 & 3 \\
\hline Sea lamprey Petromyzon marinus & 4.9 & 4.9 & 2 \\
\hline Alewife Alosa pseudoharengus & 2.4 & 2.4 & 1 \\
\hline
\end{tabular}

a Prey remains included vertebrae or vertebral columns only.

b Prey remains were distinguishable from Atlantic salmon, but no further identification was made due to the degree of digestion.

c Prey remains were not distinguishable from Atlantic salmon or other species due to the degree of digestion.

be considered as important for the time and place sampled (Harrison et al. 1983). All measurement data are reported as the mean $\pm \mathrm{SD}$.

The presence or absence of spill (enabling downstream migration of smolts without turbine passage) was monitored throughout the study. Also, we assumed that the mean diurnal water temperature $\left({ }^{\circ} \mathrm{C}, \pm \mathrm{SD}\right)$ recorded at the U.S. Geological Survey gauging station in Lowell, Massachusetts, was reflective of conditions at the Essex Dam, approximately 18 river $\mathrm{km}$ downstream.

\section{Results}

We captured 212 striped bass during sampling on $6,8,13,14,21$, and 28 May. Prey remains were recovered from 41 individuals. Ranges for mass and fork length of striped bass were $0.11-5.10 \mathrm{~kg}$ (mean, $0.93 \pm 0.58 \mathrm{~kg}$ ) and $30-78 \mathrm{~cm}$ (mean, $40.37 \pm 6.34 \mathrm{~cm})$, respectively. The estimated age of striped bass ranged from 2.5 to 9.5 years (mean, $3.5 \pm 1.0$ years). Striped bass containing smolts or prey remains resembling but not definitely identified as smolts (see below) ranged in mass from 0.57 to $4.65 \mathrm{~kg}(1.33 \pm 0.76 \mathrm{~kg})$, in fork length from 38 to $69 \mathrm{~cm}(44.62 \pm 6.46 \mathrm{~cm})$, and in age from 2.5 to 7.5 years $(4.0 \pm 1.1$ years $)$.

Six categories of prey remains were recovered (Table 1), however the greatest number of prey categories recovered from any stomach was two. Atlantic salmon smolts were the predominant prey recovered based on the three statistics used (Table 1) and represented more than $80 \%$ of the approximately $1,000 \mathrm{~g}$ of prey remains recovered. Recovered smolts with length grades of 1 and $2(N$ $=15)$ ranged from 8.9 to $19.1 \mathrm{~cm}(15.2 \pm 3.1$ $\mathrm{cm})$, whereas the fork length of smolts stocked in 
the Merrimack River ranged from 11.5 to $24.5 \mathrm{~cm}$ (based on a prestocking sample of 865 fish from rearing pools at the Green Lake National Fish Hatchery; USFWS, unpublished data); $97.7 \%$ were greater than or equal to $16.5 \mathrm{~cm}$. After examining both fork length and scale growth of 23 smolts recovered from striped bass, we considered 14 to have been stocked as smolts, 6 stocked as fry, and 3 were of unknown origin. Smolts suspected to be of stocked-fry origin ( $N=6$ of length grade 1 or 2) ranged from 8.9 to $16.7 \mathrm{~cm}(12.5 \pm 2.6 \mathrm{~cm})$, whereas smolts identified as of stocked-smolt origin ( $N=7$ of length grade 1 or 2$)$ ranged from 13.8 to $19.1 \mathrm{~cm}(17.2 \pm 2.0 \mathrm{~cm})$.

Diurnal river temperature during the study ranged from $10^{\circ} \mathrm{C}$ to $15^{\circ} \mathrm{C}\left(12.2 \pm 1.4^{\circ} \mathrm{C}\right)$ with the lowest and highest temperatures recorded on 7 and 28 May, respectively. Spill at the dam, though minimal at times, was present throughout the sampling period.

\section{Discussion}

We observed no evidence of prior injury to smolts recovered from striped bass. Still, internal injury and decreased predator avoidance behavior resulting from dam passage (Raymond 1979) cannot be dismissed. Further, of those smolts for which an accurate fork length was obtained (including both stocked-fry and stocked-smolt origin fish), approximately $53 \%$ were less than $16.5 \mathrm{~cm}$ long, falling within the smaller size ranges of stocked smolts. In addition, though our sample size of intact fish of stocked-smolt origin was small $(N$ $=7)$, the mean fork length of these individuals $(17.2 \mathrm{~cm})$ also fell within the smaller size ranges of stocked smolts $(9.5 \%<17.5 \mathrm{~cm})$. Our data, however, are insufficient to assign a biological significance to these differences.

We note that it is possible that smolts of stockedfry origin and individuals stocked as smolts in April may have migrated past the Essex dam before 6 May or after 28 May. Peaks in smolt migration from the headwaters of the Merrimack River have been recorded from 20 May to 2 June with some fish moving as late as 10 June (J. F. McKeon, USFWS, unpublished data). Further, representative samples of the striped bass population foraging in the tailrace of the Essex Dam or the prey species consumed by these fish were probably not obtained. However, these data provided the first evidence that striped bass consume Atlantic salmon smolts during the riverine phase of migration. Further, the information gathered in this pilot study has provided a foundation for a full investigation, that began in 1998, with the purpose of quantifying striped bass predation at the Essex Dam.

\section{Acknowledgments}

Funding for this pilot study was provided by the U.S. Forest Service through the Northeast Forest Experimental Station at the University of Massachusetts, Amherst, the National Marine Fisheries Service, Cooperative Marine Education and Research Program, at the University of Massachusetts, Amherst, and the Cooperative State Research, Extension, and Education Service, U.S. Department of Agriculture, Massachusetts Agricultural Experiment Station, project MAS00788. Consolidated Hydro, Inc., provided access to the Essex Dam. A sample of smolts was provided by P. Gaston, USFWS, Green Lake National Fish Hatchery, to serve as our reference group for identification of smolt remains. Laboratory space, equipment, and assistance in aging smolts and striped bass were provided by J. F. McKeon, USFWS, Office of Fishery Assistance, Laconia, New Hampshire, and by P. Caruso, Massachusetts Division of Marine Fisheries, Pocasset.

\section{References}

Blackwell, B. F., and five coauthors. 1998. Simulating migration mortality of Atlantic salmon smolts in the Merrimack River. North American Journal of Fisheries Management 18:31-45.

Boreman, J., and R. R. Lewis. 1987. Atlantic coastal migration of striped bass. Pages 331-339 in M. J. Dadswell and five coeditors. Common strategies of anadromous and catadromous fishes. American Fisheries Society, Symposium 1, Bethesda, Maryland.

Field, J. D. 1997. Atlantic striped bass management: where did we go right? Fisheries 22(7):6-9.

Harrison, C. S., T. S. Hida, and M. P. Seki. 1983. Hawaiian seabird feeding ecology. Wildlife Monographs 8:51-72.

Hyslop, E. J. 1980. Stomach content analysis-a review of methods and their application. Journal of Fish Biology 17:411-429.

Moring, J. R. 1987. Restoration of Atlantic salmon to Maine: overcoming physical and biological problems in the estuary. Pages 3129-3140 in O. T. Magoon and five coeditors. Proceedings of Ocean Zone 1987, the fifth symposium on coastal and ocean management. American Society of Civil Engineers, New York.

Moring, J. R., J. Marancik, and F. Griffiths. 1995. Changes in stocking strategies for Atlantic salmon restoration and rehabilitation in Maine, 1871-1993. Pages 38-46 in H. L. Schramm, Jr, and R. G. Piper, editors. Uses and effects of cultured fishes in aquatic ecosystems. American Fisheries Society, Symposium 15, Bethesda, Maryland. 
Raymond, H. L. 1979. Effects of dams and impoundments on migrations of juvenile chinook salmon and steelhead from the Snake River, 1966 to 1975. Transactions of the American Fisheries Society 108: 505-529.

Reintjes, J. W., and J. E. King. 1953. Food of yellowfin tuna in the central Pacific. U.S. Fish and Wildlife Service Fishery Bulletin 54:91-110.

Robins, C. R., and G. C. Ray. 1986. A field guide to Atlantic coast fishes. Houghton Mifflin, Boston.

Scott, W. B., and M. G. Scott. 1988. Atlantic fishes of Canada. Canadian Bulletin of Fisheries and Aquatic Sciences 219.
Stolte, L. W. 1994. Atlantic salmon restoration in the Merrimack River basin. Pages 22-35 in S. Calabi and A. Stout, editors. Proceedings of the New England Atlantic salmon management conference: a hard look at some tough issues. New England Salmon Association, Newburyport, Massachusetts.

Warner, J. P., and B. Kynard. 1986. Scavenger feeding by subadult striped bass, Morone saxatilis, below a low-head hydroelectric dam. Fishery Bulletin 84: 221-222. 